\title{
MODIFIKASI MESIN PENGGORENG KRUPUK PASIR MANUAL MENJADI SEMI OTOMATIS DENGAN MIKROKONTROLLER BAHAN BAKAR GAS ELPIJI
}

Submitted

\author{
: 11 Oktober 2021
}

Accepted:

21 Desember 2021

Published : 31 Desember 2021

\begin{abstract}
Abstrak
Usaha kecil dan UMKM penghasil kerupuk pasir diwilayah Dsn.Sumbergayu, Ds.Klurahan, kec.Ngronggot kab.Nganjuk saat ini masih banyak menggunakan metode penggorengan manual dengan menggunakan tenaga manusia sebagai andalan utama. Sistem penggorengan manual yang menggunakan tenaga manusia masih menggunakan bahan bakar kayu yang dimasukkan ke dalam tungku dan membuat temperature di ruang penggorengan menjadi sangat panas sehingga membuat pekerja menjadi cepat lelah dengan keadaan tersebut dan dianggap kurang efisien. Salah satu solusi untuk menambah efisiensi dan produktifitas yaitu dengan melakukan modifikasi mesin penggoreng kerupuk menjadi semi-otomatis dengan bahan bakar gas elpiji yang dilengkapi pengatur suhu. Modifikasi mesin penggoreng kerupuk pasir semi otomatis ini bertujuan agar proses produktivitas pada penggorengan kerupuk pasir lebih optimal sehingga tidak dibutuhkan tenaga kerja tambahan dan temperatur di sekitar penggorengan lebih stabil. Modifikasi mesin penggoreng ini dimulai dari melakukan survei lapangan sehingga diperoleh gambaran mesin penggorengan yang ada sekarang, pengerjaan dibagi menjadi dua komponen utama sehingga dalam proses manufaktur lebih mudah pengerjaannya. Komponen pertama adalah sistem mekanis dan yang kedua sistem elektrik, sistem mekanis terdiri dari chas is, drum penggorengan, gear box, pully dan motor listrik sedangkan sistem elektrik terdiri dari panel dan elektrik mikrokontroller ATMEGA. Pada dasarnya mesin ini nantinya bisa digerakkan dengan menggunakan semi-otomatis dan juga bisa dengan penggerak manual.
\end{abstract}

Kata Kunci: Krupuk Pasir, Penggorengan, Produktivitas 


\section{PENDAHULUAN}

Ds. Sumbergayu, Ds.Klurahan, terletak di titik LS 7"31'0" dan BT $111^{\circ} 54^{\prime} 0^{\prime \prime}$ dengan batas-batas wilayah yakni batas utara Desa Klurahan, batas timur Desa Banjarsari, batas selatan Desa Cengkok dan batas barat Desa Mojokendil, Dsn.Sumbergayu, Ds.Klurahan, merupakan salah satu dari 13 Desa yang ada di Kecamatan Ngronggot, Kab Nganjuk dan terletak di tengah masyarakat yang berbasis Industri kecil Kerupuk Pasir .

Pandemi Covid-19 telah menjadi pandemi global dan pemerintah mengeluarkan peraturan No.21 tahun 2020 tentang Pembatasan Sosial Bersekala Besar PSBB) dalam rangka percepatan penanganan corona virus 2019 (Covid 19). Setelah PSBB, pemerintah mengeluarkan kebijakan Pemberlakuan Pembatasan Kegiatan Masyarakat (PPKM) Jawa-Bali ada awal 2021. Langkah ini diharapkan bisa menjadi momentum bagi munculnya aksi terpadu untuk mencegah penularan Covid-19 antara pusat dan daerah. Dengan adanya Pemberlakuan Pembatasan Kegiatan Masyarakat (PPKM) tanpa terasa sangat berimbas pada kegiatan Usaha
Mikro Kecil Menengah (UMKM) di Dsn.Sumbergayu, Dsn.Klurahan.

Kerupuk pasir merupakan makanan favorit masyarakat kita baik untuk camilan maupun oleh-oleh, tidak memandang masyarakat kalangan atas maupun kalangan bawah. Di berbagai daerah di Indonesia kerupuk pasir mempunyai ciri khas dan cita rasa serta ukuran yang bervariasi, tidak terkecuali di Dsn. Sumbergayu, Ds. Klurahan Kec.Ngronggot, Kab.Nganjuk ini. Kerupuk pasir yang dihasilkan dari desa ini mempunyai 4 rasa yaitu: rasa bawang, pedas manis, terasi dan rambak. Kerupuk pasir merupakan jenis kerupuk dengan sistem penggorengan yang menggunakan pasir sebagai media penggorenganya. Dengan menggunakan media pasir kerupuk akan lebih renyah dan tidak berminyak. Kendala yang dihadapi UMKM krupuk pasir adalah sulitnya mendapatkan tenaga kerja, waktu penggorengan lama, peralatan penggorengan manual dan panasnya temperatur ruang penggorengan. Tingginya temperatur ruangan penggorengan membuat pekerja mudah lelah dan dehidrasi, sehingga membuat tidak semua orang mampu bertahan lama sebagai pekerja di industri penggorengan 
krupuk ini. Belum lagi ditunjang peralatan penggorengan yang masih manual dan butuh tenaga untuk memutar drum penggorengan. Kondisi ini membawa masalah tersendiri yang mengurangi produktivitas dalam menghasilkan kerupuk pasir. Dengan melihat kondisi yang demikian, akan dilakukan perubahan pola rancangan dengan memakai motor listrik dengan dilengkapi engkol manual, dan bahan bakar menggunakan gas elpiji dan pola operasional yang otomatis.

\section{TINJAUAN PUSTAKA}

Ada beberapa penelitian dan perancangan yang telah dilakukan sebelumnaya diantaranya (Kristanto, 2009) tentang perancangan mesin penggorengan kerupuk kapasitas $60 \mathrm{~kg}$, dimana dalam melakukan perancangan dari mesin manual dengan tenaga manusia dirubah menggunakan motor listrik, tetapi ada satu sisi kelemahannya yaitu pada saat listrik mati tidak bisa dilakukan produksi penggorengan. Selanjutnya, (Steven, 2015) melakukan penyempurnaan dengan menambahkan sistem engkol manual dan dilengkapi kontrol pengatur suhu dan bahan bakar gas elpiji. Berikut adalah gambaran kondisi mesin penggorengan UMKM yang ada di Dsn. Sumbergayu, Ds.Klurahan
Kec.Ngronggot, Kab. Nganjuk.

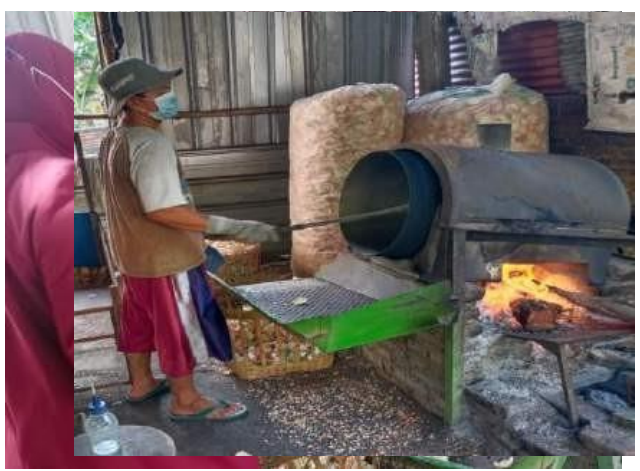

Gambar 1. Tungku Penggorengan lama

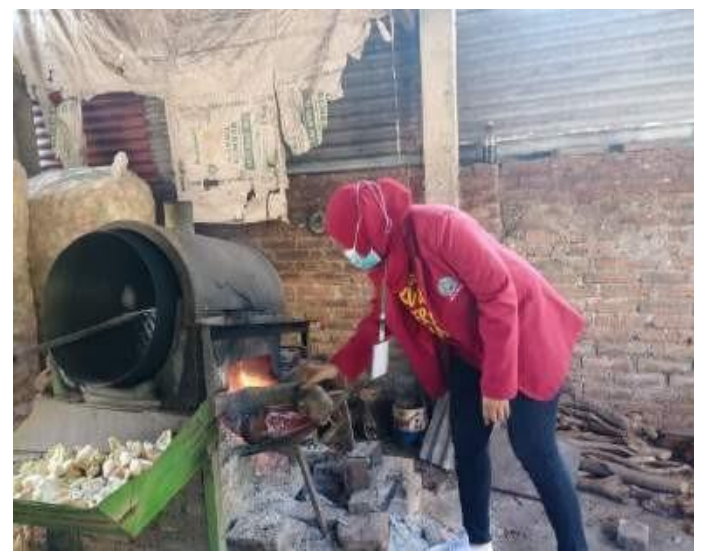

Gambar 2. Proses pemasukan kayu bakar.

Berdasarkan hasil observasi di lapangan yang telah dilakukan tim pengusul mencatat bahwa, pertama tungku penggorengan dari manual memakai tenaga manusia masih memungkinkan diubah menggunakan energi listrik dengan menggunakan electromotor (Sularso, 2004), kedua bahan bakar tungku penggorengan yang selama ini menggunakan kayu bakar dilakukan modifikasi dengan menggunakan gas elpiji sehingga ruang 
penggorengan bisa lebih dingin dan bersih dari debu kayu bakar. Temperatur ruang penggorengan juga akan dilakukan pengontrolan temperatur dengan menggunakan mikrokontroller sehingga akan didapatkan temperatur yang benarbenar dibutuhkan saat penngorengan, dan apabila ada over heat secara otomatis jumlah gas akan diatur menggunakan solenoid vale yang akan mengontrol jumlah volume gas yang dialirkan ke dalam bunner penggorengan.

Pada kesempatan ini, tim akan melakukan penyempurnaan terhadap pemakaian ECU ( Engine Control unit) dengan merubah menggunakan mikrokontroller ATMEGA diharapkan mampu memperoleh efisiensi dalam penggunaan bahan bakar dan bisa lebih maksimal untuk melakukan kontrol terhadap suhu dan konsumsi bahan bakar.

\subsection{Mikrokontroller}

Mikrokontroler adalah sebuah sistem komputer fungsional dalam sebuah chip. Di dalamnya terkandung sebuah inti prosesor, memori (sejumlah kecil RAM (Random Access
Memory), memori program, atau keduanya), dan perlengkapan input output (Andrianto, 2016).

Mikrokonktroller digunakan dalam produk dan alat yang dikendalikan secara otomatis, seperti sistem kontrol mesin, remot kontrol, mesin kantor, peralatan rumah tangga, alat berat, dan mainan. Saat ini, mikrokontroller yang banyak beredar di pasaran adalah mikrokontroller 8 bit varian jenis mikrokontroller MCS51 (CISC) yang dikeluarkan oleh Atmel dengan seri AT89Sxx, dan mikrokontroller AVR yang merupakan mikrokontroller RISC dengan seri ATMEGA8535 (walaupun varian dari mikrokontroller AVR sangatlah banyak, dengan masing-masing memiliki fitur yang berbeda-beda). Dengan mikrokontroller tersebut pengguna (pemula) sudah bisa membuat sebuah sistem untuk keperluan sehari-hari, seperti pengendali peralatan rumah tangga jarak jauh yang menggunakan remote control televisi, radio frekuensi, maupun menggunakan ponsel, membuat jam digital, termometer digital dan sebagainya. 
3. METODE PELAKSAAN

\section{PENGABDIAN}

Dalam melaksanakan metode pengabdian di bagi dalam dalam empat kategori :

a. Melakukan survei tempat pelaksanaan dan menentukan mitra UMKM

b. Melakukan design dan perhitungan peralatan

c. Fabrikasi alat dan pengujian

\subsection{Menyerahkan peralatan kepada $U M K M$}

Flowchart modifikasi perancangan

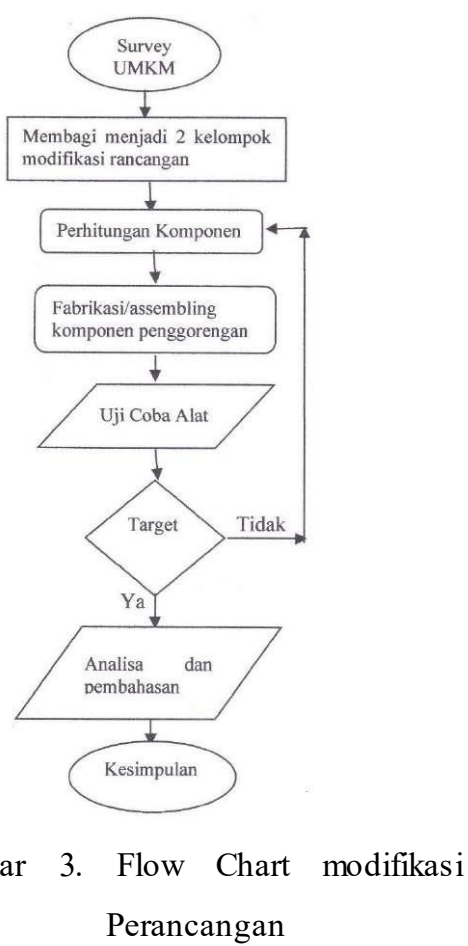

\subsection{Perancangan mekanisme mesin penggorengan}

Dalam perancangan dan modifikasi mesin penggorengan dilengkapi dengan mikrokontroller ATMEGA untuk melakukan kontrol terhadap suhu, kebutuhan bahan bakar, waktu dan lain-lain. Setelah mendapatkan referensi baik dari buku maupun jurnal, maka perancangan ini dikelompokkan menjadi 3 bagian penting :

a. Kerangka/chasis sebagai tumpuan dari sejumlah komponen yang menunjang

b. Transmisi daya meliputi: Gearbox, pully, kopling, engkol manual dan $\mathrm{v}$ belt.

c. Elektronik System meliputi panel listrik, motor listrik, mikrokontroller ATMEGA .

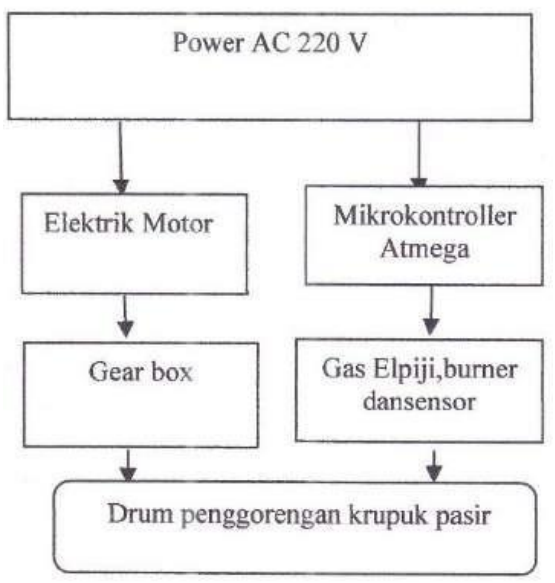

Gambar 4. Rancangan mekanisme Mesin 


\section{HASIL DAN PEMBAHASAN}

Dalam

melakukan

modifikasi

perancangan lebih banyak melakukan modifikasi terhadap sistem elektrikal dan kontrol dengan menggunakan mikrokontroller, ATMEGA dengan harapan bisa mendapatkan kontrol terhadap temperatur penggorengan, waktu putaran dan konsumsi bahan bakar gas elpiji yang lebih efisien sehingga mampu meningkatkan efisiensi dan produktivitas sehingga mampu mengangkat kesejahteraan UMKM. Dengan melihat kondisi mekanisme penggerak dengan sistem seperti di atas, maka di buatkan konsep modifikasi perancangan seperti gambar di bawah ini :

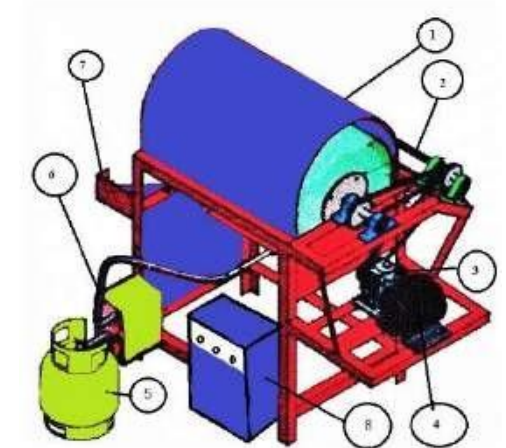

Gambar 5. Konsep design rancangan dan modifikasi penggorengan krupuk pasir

Keterangan Gambar : 1.Drum Luar, 2.Engkol pemutar manual, 3.Transmisi Gear box, 4.Motor Listrik, 5.Tabung gas Elpiji, 6.Mikrokontroller Atmega,
7.Tempat keluar Kerupuk, 8.Power supplay

Sistem elektronik Mikrokontroller ATMEGA terdiri dari komponen sebagai berikut :

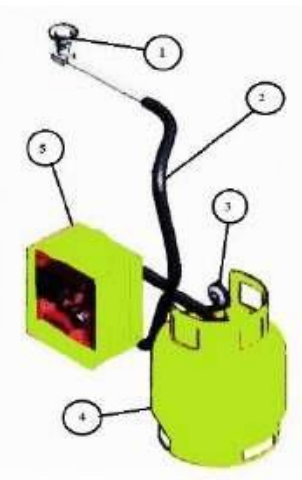

Gambar 6. Rangkaian system bahan bakar dengan mikrokontroller ATMEGA

Keterangan Gambar: 1. Burner, 2. Selang gas elpiji 3.Regulator elpiji 4.Tabung Elpiji 5.Mikrokontroller unit

\subsection{Sistem Kerja Peralatan}

Rangkaian alat ini menjadi salah satu alternatif penggorengan krupuk pasir dengan meminimalisir tenaga manusia dan sepenuhnya digerakkan dengan electro motor dan besarnya temperatur dikontrol oleh mikrokontroller sistem, dimana mikrokontroller ini yang akan mengontrol jumlah gas yang masuk ke burner. Adapun sistem kerja dari peralatan penggorengan adalah sebagai berikut : hidupkan saklar motor pada 
panel dan posisikan push bottom pada posisi on maka motor akan berputar dan menggerakkan gear box dengan perbandingan putaran yang lebih pelan dari motor. Selanjutnya gear box dengan menggunakan transmisi $\mathrm{V}$ belt akan mengerakkan drum penggorengan yang masih kosong. Tunggu sampai kondisi normal selama 5 menit dan mulailah tekan tombol mikrokontroller Sehingga gas melalui selang akan mengalir ke burner dan terjadi proses pembakaran untuk membakar drum penggorengan. Masukkan pasir kedalam drum penggorengan dan tunggu selama 10 menit atau panel mikrokontrollr sudah berhenti nyala merah / pilot lamp warna merah padam ,sebagai tanda temperature di dalam drum penggorengan sudah siap dimasukkan krupuk. Masukkan krecek/krupuk mentah ke dalam drum penggorengan tunggu sampai krupuk berwarna cerah dan tiriskan melalui lubang pengeluaran dan kumpulkan di penampungan. Kemudian, krupuk dipilah untuk dilakukan pengemasan/packaging dalam plastik dan siap dipasarkan.

\subsection{Spesifikasi Mesin penggoreng kerupuk}

Dari hasil modifikasi dan perancangan diperoleh spesifikasi yang sesuai dengan kebutuhan dan performa yang maksimal. Perancangan dan modifikasi mesin penggoreng krupuk semi otomatis dilengkapi pengatur suhu, dilakukan mulai proses perancangan sampai pembuatan gambar kerja dengan spesifikasi umum pada mesin sebagai berikut :

- Dimensi Rangka Panjang = $1100 \mathrm{~mm}$ Lebar $=550 \mathrm{~mm}$ Tinggi $=1150 \mathrm{~mm}$

- $\quad$ Daya Motor $=3 / 4$ HP

- $\quad$ Reducer $=1: 10$

- $\quad \mathrm{V}$-Belt $=$ Bando Tipe $-\mathrm{A}$

- $\quad$ Bantalan $1=$ SKF P205

- $\quad$ Bantalan $2=$ SKF PH 204

- $\quad$ Drum $=\varnothing 500 \mathrm{~mm}$

- $\quad$ Selenoid Valve $=8$ Bar

\section{KESIMPULAN}

Dalam melakukan modifikasi dan perancangan mesin penggorengan krupuk pasir dilakukan dengan tidak mengubah fungsi asasi alat tersebut, tetapi dengan tambahan melakukan pembaharuan dalam bidang teknologi kekinian. Adapun teknologi kekinian yang dilakukan pembaharuan di antaranya :

- Peralatan mekanis meliputi chasis, drum penggorengan, transmisi/gear box, pully dan motor listrik, dimana 
motor listrik sebagai penggerak, puli, dan belt sebagai Transmisi penggerak .

- Kontrol sistem otomatis yang dilakukan oleh mikrokontroller ATMEGA melakukan kontrol terhadap temperature penggorengan, jumlah bahan bakar elpiji yang masuk dan mengatur besarnya api yang membakar drum penggorengan. Spesifikasi umum pada mesin sebagai berikut :

- Dimensi Rangka Panjang = $1100 \mathrm{~mm}$

- Lebar $=550$ $\mathrm{mm}$ Tinggi $=$ $1150 \mathrm{~mm}$

- $\quad$ Daya Motor =3/4 HP

- $\quad$ Reducer $=1: 10$

- $\quad \mathrm{V}$-Belt $=$ Bando Tipe $-\mathrm{A}$

- $\quad$ Bantalan 1 = SKF P205

- $\quad$ Bantalan 2 = SKF PH 204

- $\quad$ Drum $=\varnothing 500 \mathrm{~mm}$

- $\quad$ Selenoid Valve $=8$ Bar

\section{UCAPAN TERIMAKASIH}

Pada kesempatan ini penulis mengucapkan banyak terima kasih kepada semua pihak yang telah membantu dalam menyelesaikan program KKN BTV (Back to village) kediri raya yang salah satu bentuk luaranya adalah publikasi jurnal pengabdian masyarakat.Terima kasih kami sampaikan kepada :

1. Kepala Desa Klurahan yang telah memberikan kesempatan KKN.

2. UMKM Kerupuk Pasir.

3. LPPM UM Surabaya

\section{DAFTAR PUSTAKA}

Andrianto. (2016). Arduino belajarcepat dan pemrograman. Bandung: Informatika.

Kristanto. (2009). Perancangan mesin penggoreng kerupuk pasir kpasits $60 \mathrm{Kg}$. Malang: UMM Repository. Steven. (2015). Rancang bangun mesin penggorengan kerupuk pasir semi otomatis dilengkapi pengatur suhu. Rekayasa Mesin , 53-57.

Sularso. (2004). Dasar Perancangan dan pemilihan elemen mesin . Jakarta: PT.Pradnya Paramita. 